\title{
Remote Sensing Satellite Imagery and In-Situ Data for Identifying Geothermal Potential Sites: Jaboi, Indonesia
}

\author{
Muhammad Isaa,*, Dwiky Pobri Cesarian ${ }^{b}$, Ismail Ahmad Abirb, Elin Yusibania, \\ Muhammad Syukri Surbaktia, Muksin Umara
}

aDepartment of Physics, Universitas Syiah Kuala 23111, Banda Aceh, Indonesia

${ }^{b}$ School of Physics, Universiti Sains Malaysia 11800, Pulau Penang, Malaysia

\begin{abstract}
Remote sensing makes it possible to map potential geothermal site for a large area effectively using thermal infrared. The purpose of the present research is to overlay ground temperature, resistivity and satellite retrieved temperature in identifying geothermal potential site in Jaboi, Sabang-Indonesia. The data of acquisition of the DEM imagery was January 3rd, 2009 and the Landsat 8 imagery is July 18th, 2017. The satellite data were applied to extract the land surface temperature and land classification across. Two supporting data in situ were used to validate the results from remote sensing. First dataset was ground temperature measurements with total 114 points and second dataset was vertical electrical sounding (VES) with total of 51 points. Satellite, VES and ground temperature data were processed and analysed using the Envi 5.3, PCI Geomatica 2016 and ArcMap 10.4. The results from each data were integrated to produce a map shows geothermal potential. Its integration produced four areas which were considered to have high geothermal potential. However, these areas vary in term of the clustering of the features of interest, for example lineament and drainage density of the area, high temperature in the surface area, fault existence and low resistivity subsurface. All the features must take into consideration to rank potential area which has higher potential. Finally, a map of geothermal potential across were successfully created as an insight for future reference. C2020. CBIORE-IJRED. All rights reserved
\end{abstract}

Keywords: Geothermal; energy; temperature; satellite data; electricity

Article History: Received: $28^{\text {th }}$ January 2020; Revised: $15^{\text {th }}$ Febryary 2020; Accepted: 19th February 2020; Available online: $5^{\text {th }}$ May 2020 How to Cite This Article: Isa M, Cesarian D.P. Abir I.A, Yusibani E, Surbakti M.S, Umar M, (2020) Remote Sensing Satellite Imagery and In-Situ Data for Identifying Geothermal Potential Sites: Jaboi, Indonesia. International Journal of Renewable Energy Development, 9(2), 237-245. https://doi.org/10.14710/ijred.9.2.237-245

\section{Introduction}

Heat source that is trapped under the Earth's crust well is known as geothermal. Volcanoes, fumaroles, hot springs and other geological thermal phenomenon on the surface of the earth are the manifestation of the geothermal hotspots site (low or high temperature) beneath the surface (Bayer et al. 2019; Hochstein and Sudarman 1993; Qin et al. 2011; Taqiuddin et al. 2016; Risdianto and Kusnadi 2010). Geothermal system consists of reservoirs (hot or cold temperature). Heat sources itself, any fluids which carry and transfer the heat, and recharge areas through faults (Taqiuddin et al. 2016). The heat source under the Earth's crust is caused by tectonic plate (active) margins which represent major zones of magmatic matter that is radioactivity and cooling (Uysal 2009). The hot reservoir in the geothermal system is the bulk of rocks from which heat can be extracted. This contains various gases, vapour and fluids in relatively high temperature. The reservoir is surrounded by rocks (cold) through which water flows from the outside into the hot reservoir. The reservoir area which water flows or other fluids into the reservoir is called the recharge area. The hot fluids in the reservoir move due to buoyancy forces through a discharge area by some distance. Recognition of prospective geothermal site in the aseismic geologic setting using conventional techniques is much challenging and costly. Therefore, the remote sensing technology applicability to detect spatial patterns such as thermal anomaly offers a cheap and useful technique (Calvin and Pace 2016). Remote sensing technology began to be developed and used after the World War II where it is limited to military use only. Over time, remote sensing began to be more developed and used widely for civil use. Remote sensing has been used in many ways including agriculture, forestry, geology, hydrology, mapping, ocean and coastal and exploration. Technological advancement in remote sensing (satellite sensor: optical or thermal) nowadays makes it feasible to map potential geothermal heat anomalies at a large scale effectively by utilizing various features aboard the satellites that can assist in determining geothermal activity such as land surface temperature, land feature classification, lineaments mapping and drainage. (Hewson et al. 2020; Hariyanto and Robawa 2016; Srivastava et al. 2010; Urai et al. 2002; Bouazouli et al. 2019; Abubakar et al. 2019). The relatively

\footnotetext{
* Corresponding author: muhammadisa@unsyiah.ac.id
} 
save time consumption, cheap and high observation accuracy makes it useful as the first phase in exploration to supply data and information for farther studies. Also, topography condition and regulation of an area such as restriction to conduct any survey on land owned by residents make it even more difficult to conduct a survey. Remote sensing technology data such as ASTER, MODIS/ASTER or MASTER, TIMS, and Landsat TM,
Landsat 7 ETM+ and Landsat 8, have thermal infrared (TIR) bands, and have been used for geothermal exploration and monitoring (Hochstein and Dickinson 1970; Hodder 1970, Dean et al. 1982; Eneva et al. 2006; Heasler et al. 2009; Qin et al. 2011; Prakash 2012; Haselwimmer et al. 2013; Fitts 2013; Mia et al. 2014; Tian et al. 2015; Nishar et al. 2016; Bromley et al. 2011 Coolbaugh et al. 2007;).

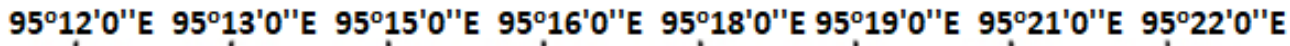

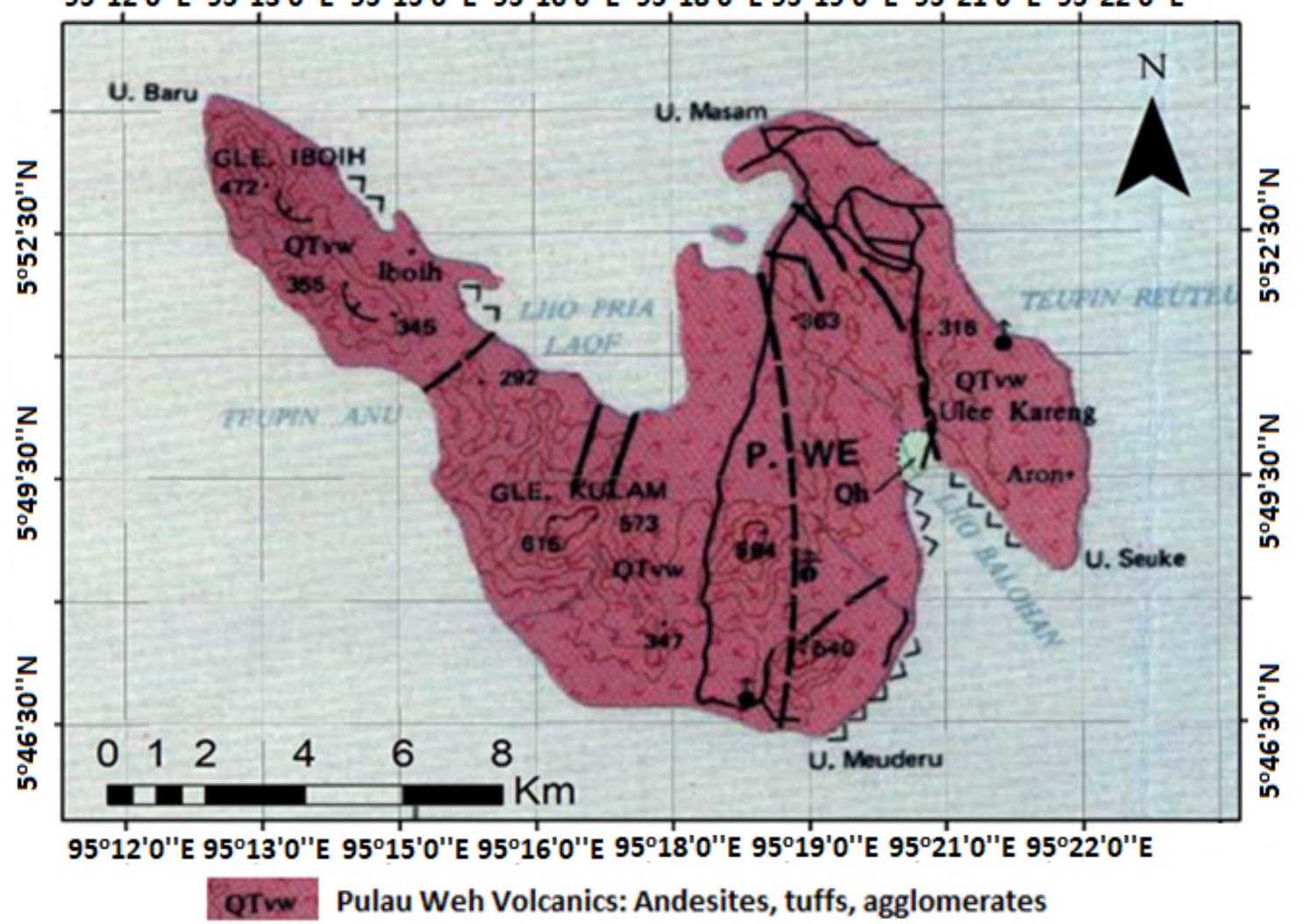

Fig. 1 The geological of the study area (modify from Geological Research and Development Centre of Indonesia, 1981).

Landsat 8 has the capability to give reliable information on surface temperature using infrared sensors (Seward et al. 2018; Sekertekin and Arslan 2019). It can retrieve not only land surface temperatures but also to obtain vegetation density which is very useful in the determination of geothermal potential site (Qin et al. 2011). Even though satellite imageries are effective, it is fundamental that ground temperature measurements are carried out to validate the data results from remote sensing. Geophysical methods such as magnetic, gravity, geo-electric survey can be performed as supportive data to validate the data measurement retrieve from remote sensing. As exploration activity dealing with uncertainty, integration of various methods must be done to get reliable results. The data from satellite imageries then will be compared with ground surveys to validate the results from remote sensing. With remote sensing method, the survey can be done by focusing only on areas that are considered to have geothermal potential. With that, the survey can be done with an efficient time and less human labor.

The study area in the present paper is in Weh Island, which located on the western tip of the Indonesian territory of Sumatera Island. Investigations have been conducted on the surface manifestations of geothermal activity (Budak 2004) and boundary manifestations in the present geothermal area (Prihadi et al. 2010). Geothermal research at Jaboi, Sabang began in 1972 with a survey (Akbar et al. 1972) and investigation of geothermal surface manifestations (Akbar and Dendi 1983). An intensive collection of geological, geochemical and geophysical studies and datasets have been developed by many authors, such as Widodo and Suhanto (2005). Moreover, Akbar (2009) formulated a geothermal conceptual model, whereas Widodo and Suhanto developed a tentative model for this region. The Jaboi geothermal area is characterized by the existence of three geothermal manifestation groups on the surface; they are geothermal Iboih, Lho Pria Laot, and Jaboi. The latest geothermal area is administratively mostly included in the Sukajaya subdistrict and a small part in Sukakarya Subdistrict, Sabang City, Aceh Province. The location can be reached by speed boat with 1.5 hours travel time from Uleelee port, Aceh to Balohan port on Weh Island, which then proceeds by road $2 \mathrm{~km}$ to the west from Balohan port. The surface manifestation of its activity can 
be indicated by hot springs, fumaroles, hot mud and hydrothermal altered area (Isa et al. 2013). Many researches have been conducted to study the geothermal activity of the present area (Dirasutisna and Hasan 2005, Dwipa et al. 2006, Munandar et al. 2007).

Figure 1 shows the geology of the study area (geological map area). The area took place in Mount Jaboi in Weh Island. The mountain is located at about $10 \mathrm{~km}$ south of Sabang city, Indonesia, with coordinate of $5^{\circ} 48^{\prime} 28.93^{\prime \prime} \mathrm{N}$ and $95^{\circ} 19^{\prime} 44.88^{\prime \prime} \mathrm{E}$. Based on the observation from the available geological map, multiple hills can be seen around the study area which may have formed from tectonic activities of the Sumatera fault system. The map suggested that the island is a volcanic island that composed of andesites, tuffs and agglomerates (Cesarian et al. 2018). Another finding on the geological condition of this island explained that stratigraphically the island consists of four main groups of rock units. The oldest rock is Tertiary sedimentary rocks followed by Tertiary-Quaternary volcanic rocks of Weh, Young/Quaternary volcanic rocks and limestone (Dirasutisna and Hasan 2005). This study aimed to identify geothermal potential sites at a large scale effectively using satellite data retrieve from Landsat- 8 and validate the retrieval results data with vertical electrical sounding, supporting data of geological map and finally ground temperature measurements.

\section{Materials and Methods}

A Landsat 8 imagery of the study are was downloaded from Earth Explorer - United States Geological Survey (USGS) with Path Type WRS 131 and Row 056 (Fig. 2(a)). The acquisition date is on July 18th, 2017. The imagery projection is UTM WGS84 Zone 46. The spatial resolution is $30 \mathrm{~m}$ for bands $1-7$ and 9, $15 \mathrm{~m}$ for 8 (panchromatic) and $100 \mathrm{~m}$ for 10 and 11 (thermal). This satellite data was applied to extract the land surface temperature and land classification across the study area. Another satellite data used in this study was the ALOS Phased Array type L-band Synthetic Aperture Radar (ALOS PALSAR DEM) data which was downloaded from the Alaska Satellite Facility website (Fig. 2(b)).
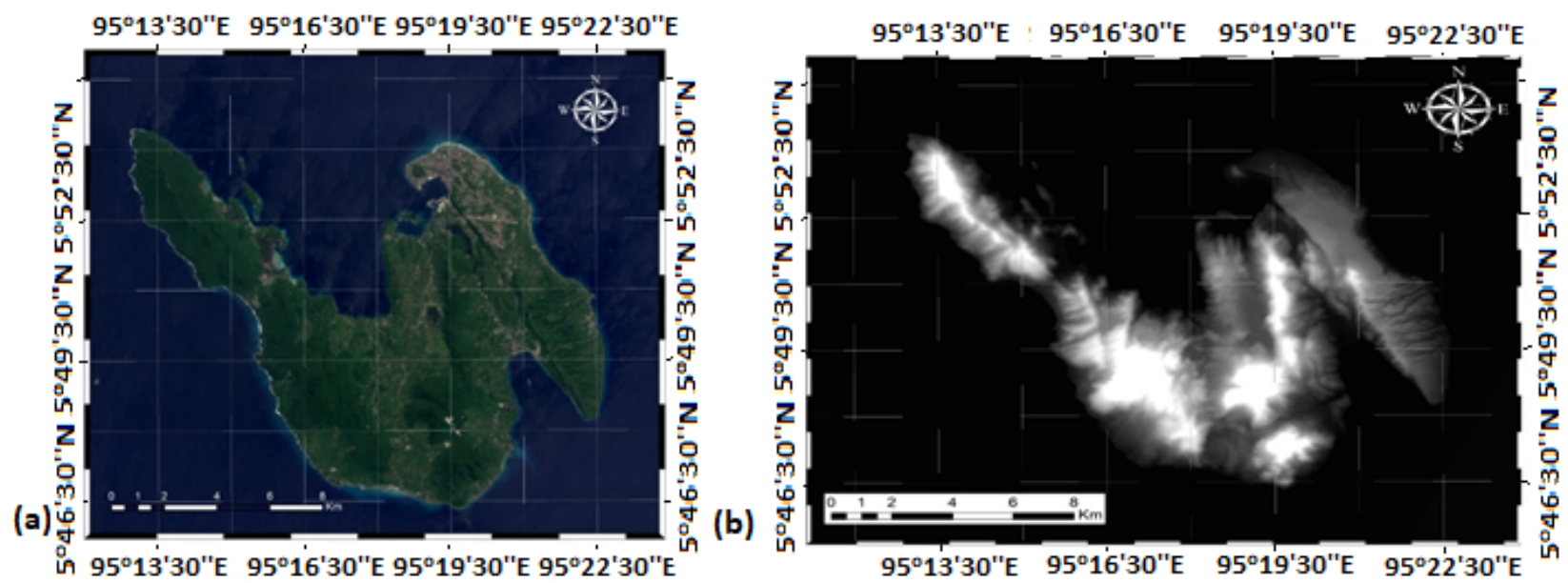

Fig. 2 (a) True color image from Landsat 8 satellite (b) ALOS PALSAR Digital Elevation Map (PALSAR DEM) of the study area

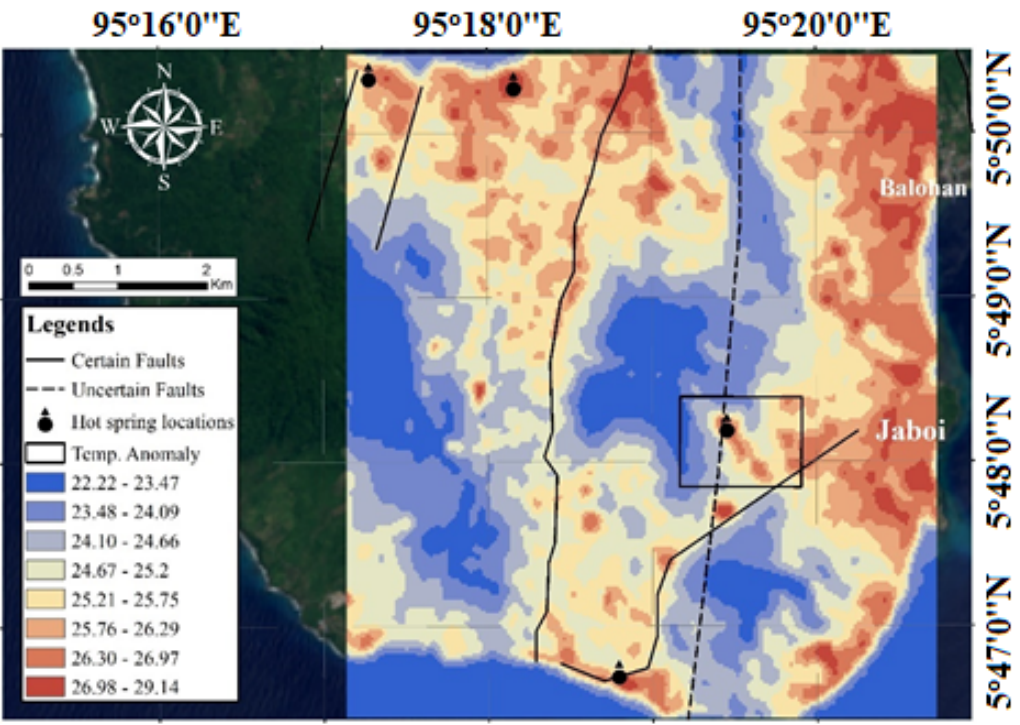

Fig. 3 (a) Land surface temperature of the present study varies from 22 to $29^{\circ} \mathrm{C}$ 
Citation: Isa M, Cesarian D.P. Abir I.A, Yusibani E, Surbakti M.S, Umar M, (2020) Remote Sensing Satellite Imagery and In-Situ Data for Identifying Geothermal Potential Sites: Jaboi, Indonesia. International Journal of Renewable Energy Development, 9(2), 237-245, doi: 10.14710/ijred.9.2.237-245

$\mathrm{P}$ a g e 240

The acquisition date of the DEM imagery was January 3rd, 2009 and it has the projection of UTM WGS84 Zone 46. The imagery spatial resolution is $12.5 \mathrm{~m}$. This satellite data was applied to extract the drainage and lineament across the study area, Jaboi Sabang. Satellite and ground temperature data were processed and analysed using the Envi 5.3, PCI Geomatica 2016 and ArcMap 10.4 softwares, while the rest of supporting data were interpolated using ArcMap 10.4. All of the results from each data were integrated to produce a map shows geothermal potential

\section{Result and Discussion}

Satellite Landsat 8 image on July 18th, 2017 were used for LST retrieval and land cover classification and ALOS PALSAR DEM on January 3rd, 2009 were used for lineament and surface drainage extraction. The Envi 5.3 and PCI Geomatica 2016 software used for processing satellite data. All the processed data were displayed with digitized fault lines and hot spring locations based on the available geological map. The land surface temperature retrieved from Landsat-8 as show in Fig. 3. The temperature ranges are 22 to $29^{\circ} \mathrm{C}$. The figure shows several locations with high temperatures over than $26^{\circ} \mathrm{C}$. Some of the locations have manmade objects (urban areas) which are capable to give relatively high temperature when monitored by the satellites, therefore, not all of them were considered as geothermal potentials site (Zhang et al. 2012). Land covers classification of four classes, showing openbare land, urban/plantation area, vegetation and water over the study area were obtained from the Landsat 8 image. Lineament extraction as indicator for possible faults or cracks (Fig. 4(a)) and surface drainage showing four orders of stream (Fig. 4(b)) over the study are were obtained from the ALOS PALSAR DEM data. $95^{\circ} 16^{\prime} 0 " \mathrm{E}$

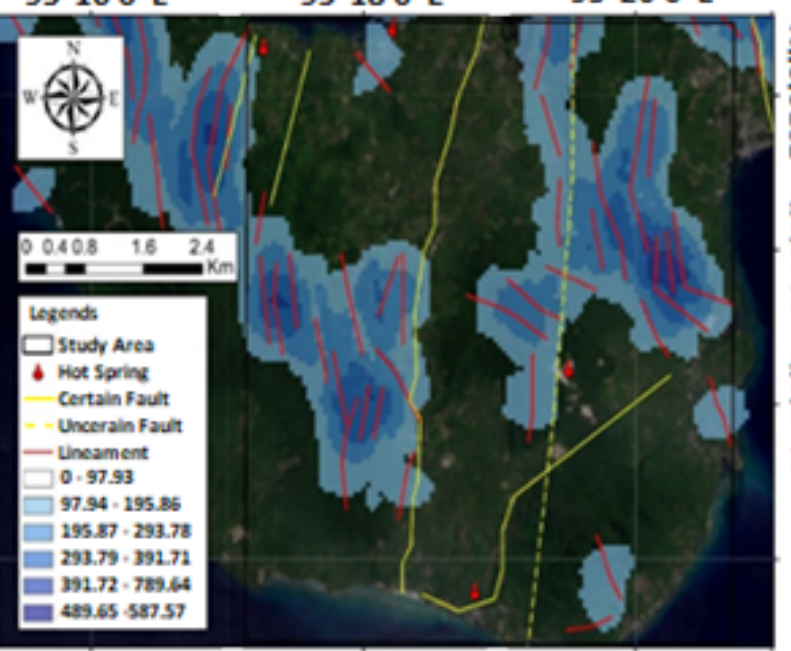

$95^{\circ} 16^{\prime} 0^{\prime \prime} \mathrm{E}$

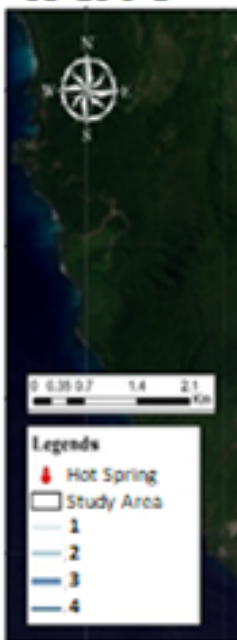

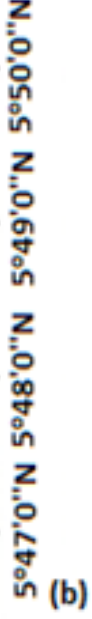

$95^{\circ} 20^{\prime} 0^{\prime \prime} \mathrm{E}$

$95^{\circ} 18^{\prime} 0^{\prime \prime} \mathrm{E}$

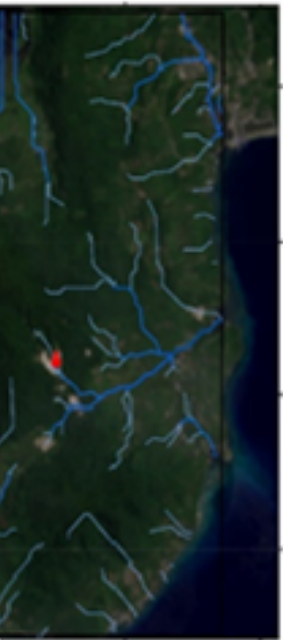

Fig. 4 (a) Lineament extraction and (b) surface drainage

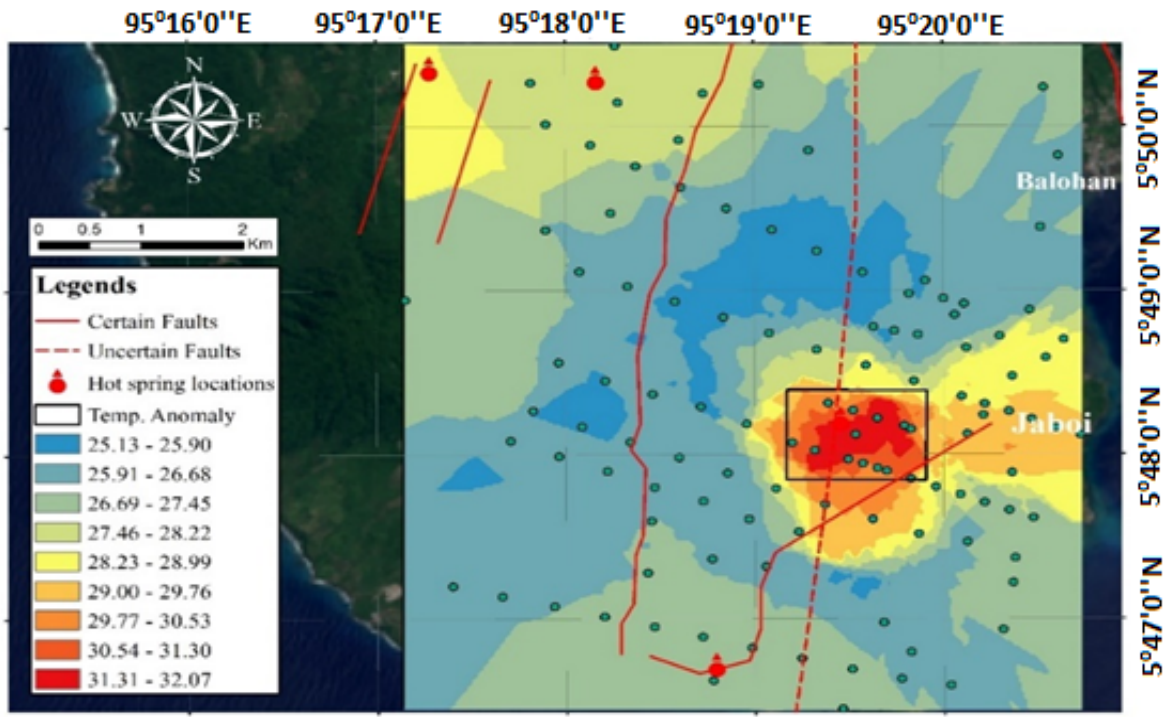

Fig. 5 Temperature distribution from ground measurements 
(a)

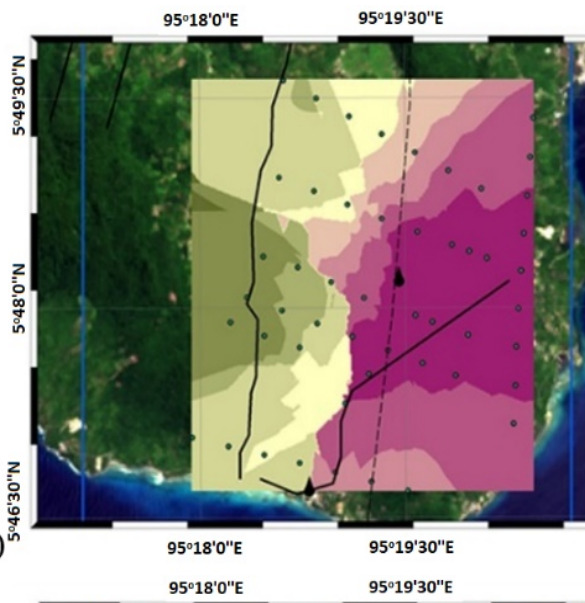

(c)

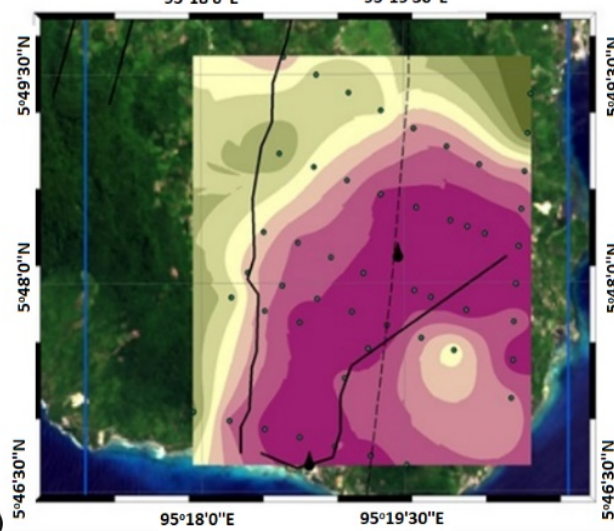

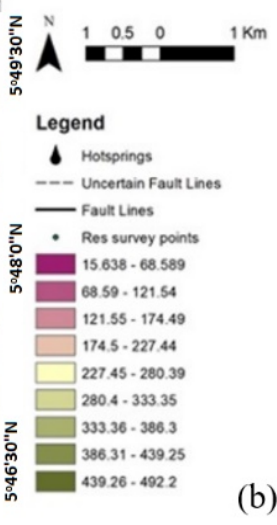

(b)
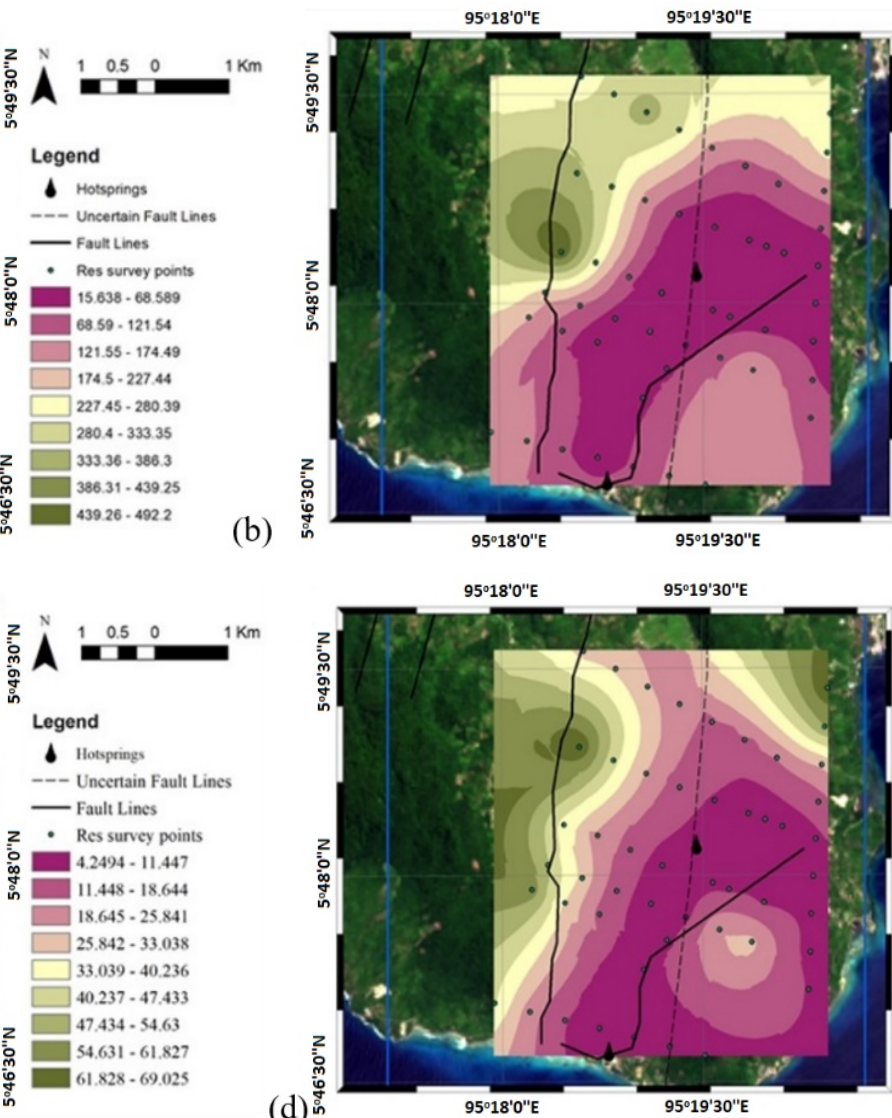

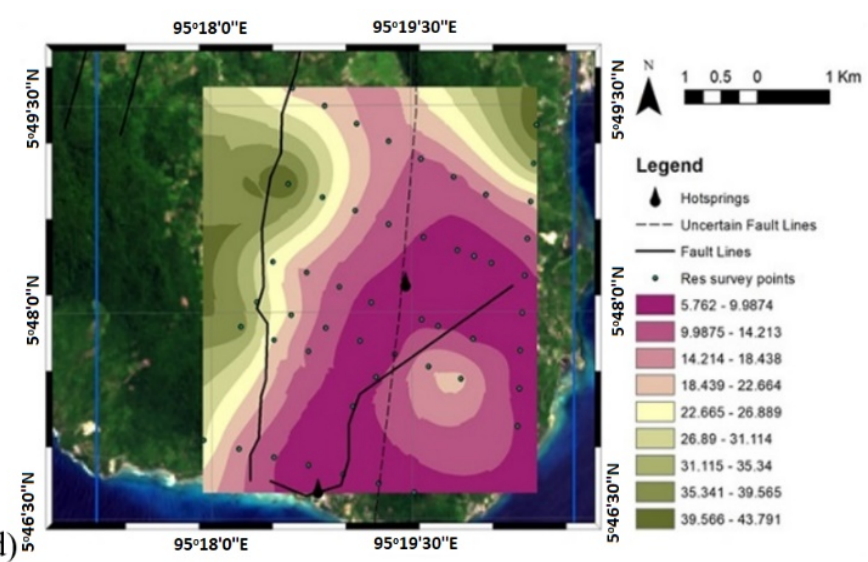

Fig. 6 The resistivity distribution across the study area of different depth (a) at $250 \mathrm{~m}$ depth, (b) at $500 \mathrm{~m}$ depth, (c) at $750 \mathrm{~m}$ depth and (d) at $1000 \mathrm{~m}$ depth.

Two supporting datasets were used to validate the retrieval data from remote sensing. First dataset was ground temperature measurements with total 114 points evenly distributed around the study area with temperature distribution varies in range of 25 to $32^{\circ} \mathrm{C}$ (Fig 5). Second dataset was vertical electrical sounding of Wenner array type with total of 51 survey points showing four different the trajectory of 250, 500, 750 and $1000 \mathrm{~m}$ (Fig. 6). Based on the integration of the obtained information, four areas were determined that have potential for geothermal, mark by number 1, 2, 3 and 4 (Fig. 7(a)). Areas 1 and 3 show high possibility for geothermal activity in the subsurface, where both have all the features even though lineaments are sparse. Areas 2 and 4 show moderate possibility in term of geothermal potential due to lack of related features. Area 2 has moderate LST, sparse drainage and no lineament in the area.
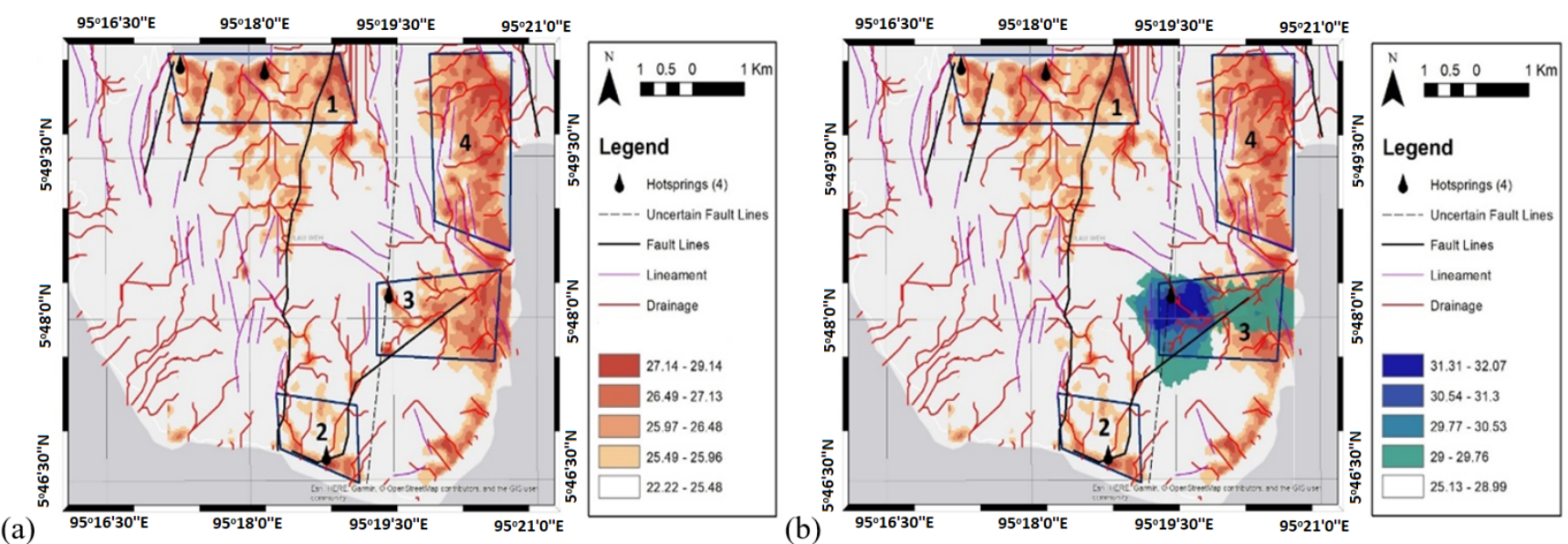

Fig. 7 (a) Integration information obtained from remote sensing data across the study area, and (b) from remote sensing and ground temperature measurement 
Citation: Isa M, Cesarian D.P. Abir I.A, Yusibani E, Surbakti M.S, Umar M, (2020) Remote Sensing Satellite Imagery and In-Situ Data for Identifying Geothermal Potential Sites: Jaboi, Indonesia. International Journal of Renewable Energy Development, 9(2), 237-245, doi: 10.14710/ijred.9.2.237-245

$\mathrm{P}$ a g e $\mid 242$

(a)
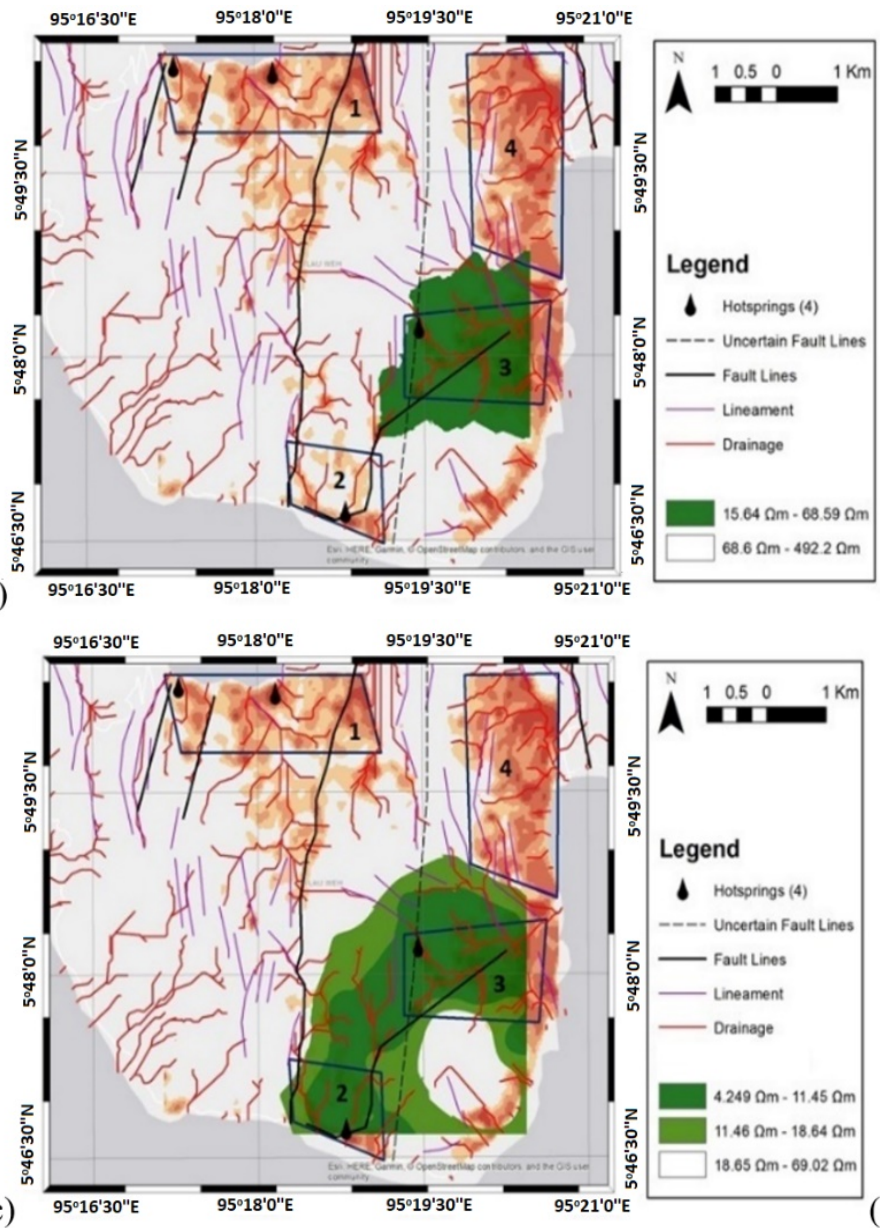

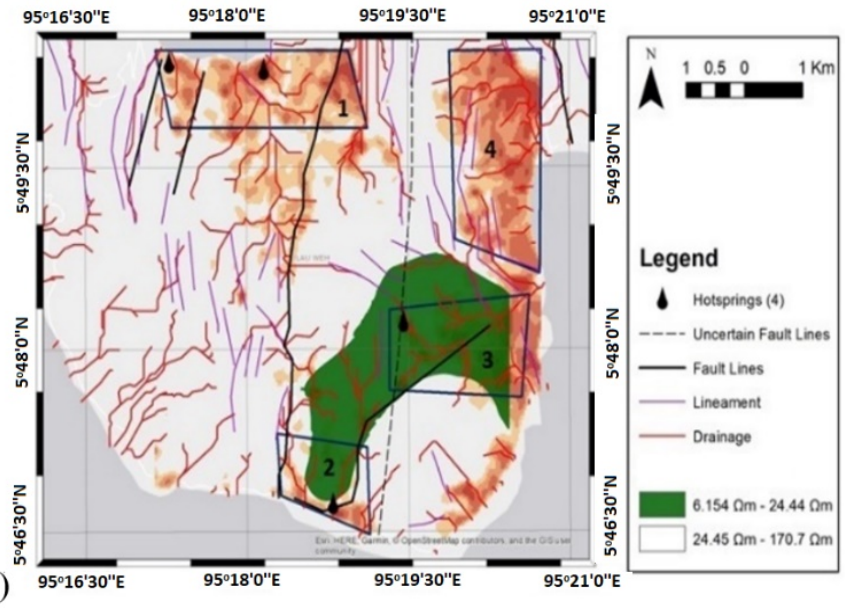

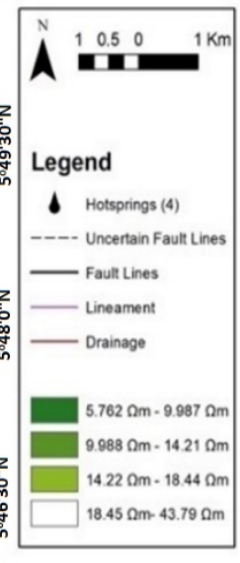

Fig. 8 Integration of obtained information from remote sensing and resistivity of distance (a) at $250 \mathrm{~m}$ (b) at $500 \mathrm{~m}$, (c) at $750 \mathrm{~m}$, and (d) at $1000 \mathrm{~m}$.

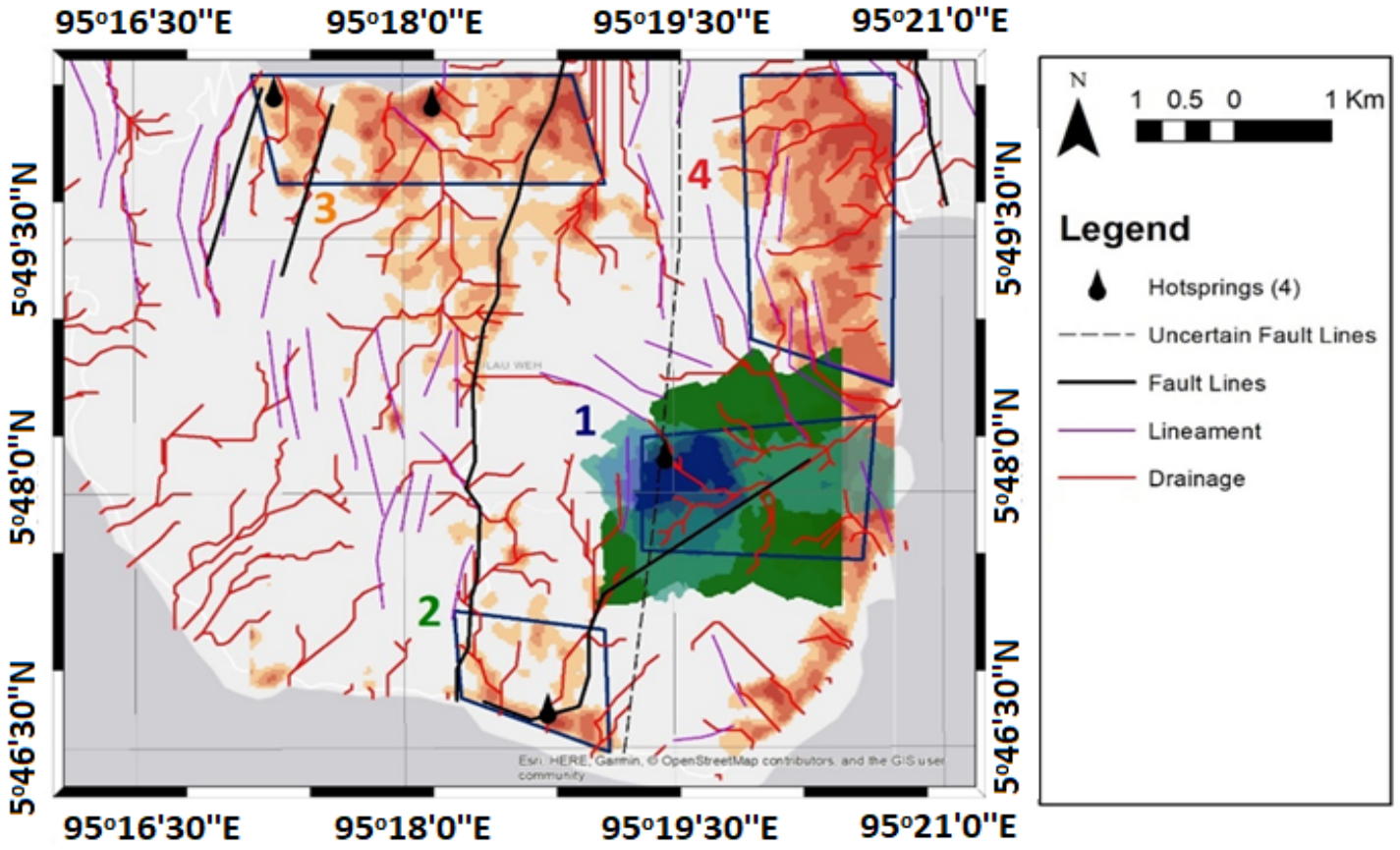

Fig. 9 Ranking for the potential of the four areas 
Table 1

Features of interest of the potential areas based on all the available datasets

\begin{tabular}{|llccccc|}
\hline & \multicolumn{1}{c}{ Potential Area } & $\mathbf{1}$ & $\mathbf{2}$ & $\mathbf{3}$ & $\mathbf{4}$ \\
\hline \multirow{2}{*}{ Remote Sensing } & Temperature & High & Moderate & High & High \\
& Drainage & Dense & Sparse & Dense & Dense \\
& Lineament & Sparse & None & Sparse & Dense \\
& Fault & $\sqrt{ }$ & $\sqrt{ }$ & $\sqrt{ }$ & $\times$ \\
& Manifestation & $\sqrt{ }$ & $\sqrt{ }$ & $\sqrt{ }$ & $\times$ \\
Ground Measurement & Heat Anomaly & $\times$ & $\times$ & $\sqrt{ }$ & $\times$ \\
Low Resistivity & $250 \mathrm{~m}$ & $\times$ & $\times$ & $\times$ & $\times$ \\
& $500 \mathrm{~m}$ & $\times$ & $\sqrt{ }$ & $\sqrt{ }$ & $\times$ \\
& $750 \mathrm{~m}$ & $\times$ & $\sqrt{ }$ & $\sqrt{ }$ & $\times$ \\
& $1000 \mathrm{~m}$ & $\times$ & $\sqrt{ }$ & $\sqrt{ }$ & $\times$ \\
\hline
\end{tabular}

Moreover, area 4 has no fault according to the available geological map and no manifestation on the surface. Figure 7(b) shows the information obtained from remote sensing method and ground temperature measurement survey overlaid on top of each other. Areas with temperature of $29^{\circ} \mathrm{C}$ and below are omitted for easy viewing when overlaid on top of LST. From ground measurement, a heat anomaly was found coinciding with potential area number 3. Resistivity values could correspond to geological features such as clay, alluvium, sand, fresh groundwater, shale and sandstone (Lichoro et al. 2017, Noorollahi et al. 2008) that for geothermal reservoirs the resistivity value is approximately $10 \Omega \mathrm{m}$. A geothermal with high clay content and high temperature contribute to a decrease in resistivity. Figure 8 shows the integration of resistivity distribution in the study area with information obtained from remote sensing. The survey conducted was not wide enough to cover all the study area resulting in the resistivity distribution covering only. Table 1 gives information of all the areas with geothermal potential from all of the available datasets. From the table, it can be seen that area 3 has all the features of interest in spite of sparse in lineament. The potential areas were ranked according to several factors regarding the features that are clustered within the area (Fig. 9).

\section{Conclusion}

Sabang has the prospect for geothermal exploration based on the existence of surface manifestations around the area. This study has applied remote sensing technique utilizing various sensors aboard the satellites to determine the potentiality for geothermal. The results have been validated by integrating it with supporting data, such as geological map in the present study, ground temperature measurement and VES. Its integration produced four areas which were considered to have high geothermal potential. Moreover, these areas vary in term of the clustering of the features of interest, such as lineament and drainage density, high surface temperature, hot spring existence, fault existence and the low resistivity subsurface. These features must take into consideration. Ranking for potential area were made to decide which area has the most potential. Area potential 3 has the highest potential for geothermal with most of the related features clustering in the area, followed by areas 2,1 and 4. Finally, roadmaps of geothermal potential in the present study were successfully created as an insight for future reference.

\section{Acknowledgments}

The research was funded by Universitas Syiah Kuala (KEMENRISTEKDIKTI) and supported by Universiti Sains Malaysia Penang.

\section{References}

Abubakar, A. J. Hashima, M. Pourc, A. B. (2019) Remote sensing satellite imagery for prospecting geothermal systems in an aseismic geologic setting: Yankari Park, Nigeria. Int $J$ Appl Earth Obs Geoinformation 80 157-172 https://doi.org/10.1016/j.jag.2019.04.005

Akbar, N. (1972) Laporan Inventarisasi Gejala Panas Bumi Pulau Weh, D.I. Aceh, Sumut dan Jambi/Kelinci. Unpublished Report Direktorat Geologi Bandung, Indonesia (in Indonesia)

Akbar, N. and Dendi, S.K. (1983) Survei kenampakan Panas Bumi di P.Weh, Kotamadya Sabang D I Aceh. Report Penyelidikan Panas Bumi, Direktorat Vulkanologi, Indonesia (in Indonesia)

Akbar, M.R. (2009) Eksplorasi panas bumi dengan metode geofisika dan geokimia, daerah Jaboi, kota Sabang Propinsi Nangroe Aceh Darussalam, Thesis, Geology Department, Institut Teknologi Bandung, Indonesia

Bayer, P. Attard, G. Blum, P. Menberg, K. (2019) The geothermal potential of cities. Renewable and Sustainable Energy Reviews 106 17-30

https://doi.org/10.1016/j.rser.2019.02.019

Budak, B. (2004) Reservoir Simulation of Balçova Geothermal Field. Dissertation Master of Science, Izmir Institute of Technology, Izmir, Turkey

Bouazouli, A. E. Baidder, L. Pasquier, P. Rhouzlane, S. (2019) Remote Sensing Contribution to The Identification of Potential Geothermal Deposits: A Case Study of The Moroccan Sahara.Rhouzlane. Materials Today: Proceedings 13 784-794

Bromley, C. J. van Manen, S. M. Mannington, W. (2011) Heat flux from steaming ground:reducing uncertainties. Proceedings of the 36th Workshop on Geothermal Reservoir Engineering. Stanford University, California, USA, SGP-TR-191.

Calvin, W. M. Pace, E. L. (2016) Utilizing HyspIRI prototype data for geological exploration applications: a southern California case study. Geosciences 6 (1), 11. 
Cesarian, D. P. Abir, I. A. Isa, M. (2018) Comparison of In-Situ Temperature and Satellite Retrieved Temperature in Determining Geothermal Potential in Jaboi Field, Sabang, IOP Conf. Series: Journal of Physics: Conf. Series 1116032008 doi:10.1088/1742-6596/1116/3/0320081

Coolbaugh, M. F. Kratt, C. Fallacaro, A. Calvin, W. M. Taranik, J. V. (2007) Detection of geothermal anomalies using Advanced Spaceborne Thermal Emission and Reflection Radiometer (ASTER) thermal infrared images at Bradys Hot Springs, Nevada, USA. Remote Sensing of Environment 106 (3), 350-359.

Dirasutisna, S. Hasan, A. R. (2005) Geologi Panas Bumi Jaboi, Sabang, Propinsi Aceh Nangroe Darussalam. Report Direktorat Inventarisasi Sumber Daya Mineral, Bandung (in Indonesia)

Dean, K. G. Forbes, R. B. Turner, D. L. Eaton, F. D. Sullivan, K. D. (1982) Radar and infrared remote sensing of geothermal features at Pilgrim Springs, Alaska. Remote Sensing of Environment 12 (5), 391-405.

Dwipa, S. Widodo, S. Suhanto, E. Kusnadi, D. (2006) Integrated Geological, Geochemical and Geophysical Survey in Jaboi Geothermal Field, Nangro Aceh Darussalam, Indonesia. The Proceedings of the 7th Asian Geothermal Symposium, Qingdao, China.

Eneva, M. Coolbaugh, M. Combs, J. (2006) Application of satellite thermal Infrared imagery to geothermal exploration in East Central California. Geothermal Resources Council Transactions 30, 407-411.

Fitts, C. R. (2013) 12 - Subsurface heat flow and geothermal energy. In: Fitts, C.R. (Ed.), Groundwater Science, second edition. Academic Press, Boston. https://doi.org/10.1016/B978-0-12-384705-8.00012-1pp. 587-620.

Hariyanto, T. Robawa, F. N. (2016) Identifikasi Potensi Panas Bumi Menggunakan Landsat 8 Serta Penentuan Lokasi Pembangkit Listrik Tenaga Panas Bumi (Studi Kasus: Kawasan Gunung Lawu). Geoid 12(1), 36-42. http://dx.doi.org/10.12962/j24423998.v12i1.2393.

Haselwimmer, C. Prakash, A. Holdmann, G. (2013) Quantifying the heat flux and outflow rate of hot springs using airborne thermal imagery: case study from Pilgrim Hot Springs, Alaska. Remote Sensing of Environment 136, 3746.

Hewson, R. Mshiu, E. Hecker, C. van der Werff, H. van Ruitenbeek, F. Alkema, D. van der Meer, F. (2020) The application of day and night time ASTER satellite imagery for geothermal and mineral mapping in East Africa. Int J Appl Earth Obs Geoinformation 85101991 https://doi.org/10.1016/j.jag.2019.101991

Hochstein, M. P. Sudarman, S. (1993) Geothermal Resources of Sumatra. Geothermics 22 (3), 181-200.

https://doi.org/10.1016/0375-6505 (93) 90042-L.

Heasler, H. P. Jaworowski, C. Foley, D. (2009) Geothermal systems and monitoring hydrothermal features. Geological Monitoring 105-140.

Hodder, D. T. (1970) Application of remote sensing to geothermal prospecting. Geothermics 2 (Part 1), 368-380.

Hochstein, M. P. Dickinson, D. J. (1970) Infra-red remote sensing of thermal ground in the Taupo region, New Zealand. Geothermics 2 (Part 1), 420-423.

Isa, M. Mat Jafri, M. Lim, H. (2013) Comparison Of Field Temperature Versus Satellite Temperature Thermal Band In Geothermal Area. The AIP Conference Proceedings, Bukit Tinggi, Pahang Malaysia.

Lichoro, C. M. Ârnason, K. Cumming, W. (2017) Resistivity Imaging of Geothermal Resources In Northern Kenya rift by joint $1 \mathrm{D}$ inversion of MT and TEM data. Geothermics. 68, 20-32.

Mia, M. B. Nishijima, J. Fujimitsu, Y. (2014) Exploration and monitoring geothermal activity using Landsat ETM+ images: a case study at Aso volcanic area in Japan.
Journal of Volcanology and Geothermal Research 275, 1421.

Munandar, A. Boegis, Z. Simarmata, R. S. (2007) Pemboran Landaian Suhu Sumur Jbo-1 dan Jbo-2 Daerah Panas Bumi Jaboi, P. Weh, Kota Sabang-Nanggro Aceh Darussalam. Report Kementrian ESDM (in Indonesian)

Nishar, A. Richards, S. Breen, D. Robertson, J. Breen, B. (2016) Thermal infrared imaging of geothermal environments and by an unmanned aerial vehicle (UAV): a case study of the Wairakei - Tauhara geothermal field, Taupo, New Zealand. Renewable Energy 86, 1256-1264.

Noorollahi, Y. Itoi, R. Fujii, H. Tanaka, T. (2008) GIS Integration Model For Geothermal Exploration And Well Siting. Geothermics 37(2), 107-131.

Prihadi, S. Kasbani, Suhanto, E. (2010) Jaboi Geothermal Field Boundary, Nanggroe Aceh Darussalam Based on Geology and Geophysics Exploration Data. Proceedings World Geothermal Congress 2010 Bali, Indonesia, 25-29 April 2010 p 1-

Prakash, H. (2012) Thermal Infrared Remote Sensing of Geothermal Systems. Springer and Praxis, pp. 500.

Qin, Q. Zhang, N. Nan, P. Chai, L. (2011) Geothermal Area Detection Using Landsat ETM+ Thermal Infrared Data And Its Mechanistic Analysis, A Case Study in Tengchong, China. Intern. J. Appl. Earth Observ. Geoinform. $\quad 13 \quad$ (4), $\quad 552-559$. http://10.1016/j.jag.2011.02.005.

Risdianto, D. Kusnadi, D. (2010) The Application of a Probability Graph in Geothermal Exploration. Proceedings World Geothermal Congress 2010 Bali, Indonesia, 25-29 April 2010.

Sekertekin, A. Arslan, N. (2019) Monitoring thermal anomaly and radiative heat flux using thermal infrared satellite imagery - A case study at Tuzla geothermal region, Geothermics 78 243-254

https://doi.org/10.1016/j.geothermics.2018.12.014

Seward, A. Ashraf, S. Reeves, R. Bromley, C. (2018) Improved environmental monitoring of surface geothermal features through comparisons of thermal infrared, satellite remote sensing and terrestrial calorimetry, Geothermics 73 6073 https://doi.org/10.1016/j.geothermics.2018.01.007

Srivastava, P. Majumdar, T. Bhattacharya, A. K. (2010) Study of Land Surface Temperature and Spectral Emissivity Using Multi-Sensor Satellite Data. J. Earth Syst. Sci. 119(1), 67-74

Taqiuddin, Z. Nordiana, M. Rosli, S. (2016) Utilizing of Geophysical Method for Geothermal Exploration In Aceh Besar (Indonesia). Intern. Res. J. Eng. Technol. 03 (04).

Tian, B. Wang, L. Kashiwaya, K. Koike, K. (2015) Combination of well-logging temperature and thermal remote sensing for characterization of geothermal resources in Hokkaido, Northern Japan. Remote Sensing 7 (3), 2647-2667.

Urai, M. Muraoka, H. Nasution, A. (2002) Satellite Remote Sensing Data and Their Interpretations for Geothermal Applications: A Case Study on the Ngada District, Central Flores, Indonesia. Bulletin-Geological Survey Japan 53(2/3), 99-108

Uysal, T (2009) Tracing the Origin of Heat Anomalies in Hot Sedimentary Aquifer System in Australia (available online at: http://Geothermalenergy centre of Excellence .org)

Widodo, S. Suhanto, E. (2005) Penyelidikan Head On di Daerah Panas Bumi Jaboi Wilayah Kota Sabang - Provinsi Nangroe Aceh Darussalam. Report Subdit Panas Bumi Direktorat Inventarisasi Sumber Daya Mineral Badan Geologi Kementerian Energi dan Mineral Republik Indonesia (in Indonesian)

Zhang, N. Qin, Q. He, L. Jiang, H. (2012). Remote sensing and GIS based geothermal exploration in southwest Tengchong, China. Paper presented at the Geoscience and Remote Sensing Symposium (IGARSS), 2012 IEEE International. 
(c) (i) (c) 2020. This article is an open access article distributed under the terms and conditions of the Creative Commons 